\title{
Effect of soaking and sprouting treatment on germination rate of paddy
}

\author{
Natthaporn Chatchavanthatri ${ }^{1}$, Tiraporn Junyusen ${ }^{1}{ }^{*}$, Pornpimol Moolkaew ${ }^{1}$, Weerachai \\ Arjharn $^{1}$, and Payungsak Junyusen ${ }^{1}$ \\ ${ }^{1}$ Suranaree University of Technology, Institute of Engineering, School of Agricultural Engineering, \\ Thailand
}

\begin{abstract}
The aim of this study was to determine the effect of germination process (i.e., soaking time and temperature, germination time, and ultrasound treatment) on the germination rate of germinated paddy. In addition, gamma-aminobutyric acid (GABA) content, and morphology of starch granule of dehulled germinated paddy (germinated brown rice, GB) were characterized. The results showed that extended soaking time from $4 \mathrm{~h}$ to $24 \mathrm{~h}$ insignificantly increased the germination rate, and increased soaking temperature from $30^{\circ} \mathrm{C}$ to $40^{\circ} \mathrm{C}$ had no effect on germination rate ( $>0.05$ ). However, extended germination time from $14 \mathrm{~h}$ to $48 \mathrm{~h}$ significantly improved the germination rate, given soaking time and temperature of 2-8 h at $30^{\circ} \mathrm{C}(\mathrm{p}<0.05)$. Ultrasound treatment for $15 \mathrm{~min}$ after $8 \mathrm{~h}$ soaking significantly increased the germination rate of $24 \mathrm{~h}$ germination, compared with non-ultrasound and ultrasound treatment for $15 \mathrm{~min}$ before $8 \mathrm{~h}$ soaking. Meanwhile, extended germination time to $48 \mathrm{~h}$, the ultrasound treatment had no effect on the germination rate $(\mathrm{p}>0.05)$. The germination process did not affect the morphology of the GB starch granule, compared with brown rice (BR). However, GABA content of GB $(11.67 \mathrm{mg} / 100 \mathrm{~g})$ was significantly higher than that of BR $(1.08 \mathrm{mg} / 100 \mathrm{~g})(\mathrm{p}<0.05)$.
\end{abstract}

\section{Introduction}

Kao Dok Mali 105 referred to "jasmine rice" is one of the most popular rice variety in Thailand because of its pleasant aroma and soft texture [1, 10]. Germinated brown rice (GB) is well-known in high nutritional benefit over brown rice (BR) and polished rice (white rice) $[2,9,12]$. Gamma-aminobutyric acid (GABA) synthesized during germination is an interesting nutrient found in GB that promotes a human health such as reduction of stresses in brain, prevention of blood pressure and diabetes, and inhibition of cancer cell proliferation $[8,9]$.

The germination process for production of GB can be divided into two-steps; soaking and sprouting (germinating) processes. The germinated seed was considered when the radicle (root) projected at least $1 \mathrm{~mm}$ [4]. The germination process conditions directly affect the germinated seed quality; especially in nutritional value and textural properties $[6,8,9]$. [5]

*Corresponding author: tirapo@sut.ac.th 
optimized the germination conditions to maximize the phytochemical and antioxidant compounds in Ecuadorian brown rice. Soaking process was at $28^{\circ} \mathrm{C}$ for $24 \mathrm{~h}$, while germination temperatures and times were varied between 28 and $34^{\circ} \mathrm{C}$; and 48 and $96 \mathrm{~h}$. Germination rate and GABA content were increased when extended the germination temperature and time. In [8], germination times for 60,64 , and $68 \mathrm{~h}$ at $35^{\circ} \mathrm{C}$ were studied to improve the quality of Chai Nat 1 germinated paddy. Extended germination time could enhance the GABA content and soft texture of germinated paddy.

Ultrasound, a non-thermal processing technique, is commonly applied in a frequency between $20-100 \mathrm{kHz}$ to improve the efficiency in the food processing. Ultrasound has been used to stimulate the germination and to enhance the bioactive compounds of germinated seed. In [3], application of ultrasound to soaked rice for $5 \mathrm{~min}$ improved GABA content of germinated rice $(72.07 \mathrm{mg} / 100 \mathrm{~g})$, while ultrasound treatment prior soaking for $5 \mathrm{~min}$ did not increase the GABA content $(2.91 \mathrm{mg} / 100 \mathrm{~g})$. In contrast, [13] reported that ultrasound treatment before the germination process effectively stimulated the germination and enhanced the bioactive compounds. Previous studies involving the effect of soaking, sprouting, and ultrasound treatments on germination rate of the Khao Dok Mali 105 paddy are still very limited.

Therefore, the objective of this study was to determine the effect of germination process (i.e., soaking conditions, germination time, and ultrasound treatment) on the rate of germination of the Khao Dok Mali 105 paddy. The chemical composition, GABA content, and microstructure of starch granule of germinated brown rice (GB) were also analyzed, and results were compared with the brown rice (BR).

\section{Materials and methods}

\subsection{Materials}

Paddy of jasmine variety (Oryza sativa L. cv. Khao Dok Mali 105) was received from Nakhon Ratchasima, Thailand. The paddy was sun dried to get a moisture content of $12-14 \%$ (wet basis) using a moisture tester (Steinlite SB900, KS, USA). The paddy was dehulled using a rice dehuller (Natrawee NW 150, Thailand) to obtain brown rice (BR) as a control. The paddy and $\mathrm{BR}$ were then vacuum packed and stored at $4{ }^{\circ} \mathrm{C}$ for further experiment. In this study, all chemicals were of analytical grade.

\subsection{Preparation of sample}

\subsubsection{Effect of soaking conditions}

The germination process was prepared by two steps: soaking and germinating, following [2] with some modifications. Paddy ( $1 \mathrm{~kg}$ ) was soaked with $0.1 \%$ sodium hypochlorite for 10 min in order to sterilizing the paddy surface. It was then washed by distilled water for three times. The sample was subjected to distilled water with a seed to water ratio of 1:2 (w/v) and incubated in a water bath at $30 \pm 2^{\circ} \mathrm{C}$ and $40 \pm 2^{\circ} \mathrm{C}$, where the soaking times were varied between $0,2,4,6,8,12$, and $24 \mathrm{~h}$. The soaked paddy was transferred into plastic basket with two layers of hemp sack laying on the bottom, and certain water was added to keep the sack moist. This basket was then covered by two layers of moist hemp sack. It was subsequently germinated at $30 \pm 2^{\circ} \mathrm{C}$ for $48 \mathrm{~h}$. The germination rate was measured following the procedure in [5] with some modifications. Briefly, 300 seeds were sampled from the germinated basket. These seeds were carefully investigated and the germinated seeds were counted. The 
germinated seed was defined when the radicle projected at least $1 \mathrm{~mm}$ [4]. The percentage of germination rate was calculated by

$$
\text { Germination rate }(\%)=\frac{\text { Germinate seeds }}{\text { Total seeds }} \times 100
$$

Based on previous studies, the germinated paddy obtained under $24 \mathrm{~h}$ soaking time at $30^{\circ} \mathrm{C}$, and $48 \mathrm{~h}$ germination period was selected for chemical and microstructural characterizations. The germinated paddy was sun dried and the moisture content was $12-14 \%$ (wet basis). The sample was then dehulled to obtain germinated brown rice (GB). The product was then vacuum-paced and stored at $4^{\circ} \mathrm{C}$ for further analysis.

\subsubsection{Effect of germination time}

The surface sterilized paddy was soaked in distilled water at $30^{\circ} \mathrm{C}$ (based on previous results), while the soaking time was varied between $2,4,6$, and $8 \mathrm{~h}$. The germination was carried out at $30 \pm 2^{\circ} \mathrm{C}$ for $14,24,36$, and $48 \mathrm{~h}$. The germination rate was investigated as described above.

\subsubsection{Ultrasound treatment}

Ultrasound was applied to improve the germination rate of germinated paddy. A $1 \mathrm{~kg}$ surface sterilized paddy was dispersed in $2 \mathrm{~L}$ distilled water in an ultrasonic bath $(35 \mathrm{kHz}$, DT 514 $\mathrm{BH}$, Bandelin, Germany). According to previous studies, the ultrasonic treatment was carried out at $30^{\circ} \mathrm{C}$ for $15 \mathrm{~min}$ before and after soaking process. In this study, soaking time and temperature of $8 \mathrm{~h}$ and $30^{\circ} \mathrm{C}$ were performed, where the germination times were varied between 14, 24, 36, and $48 \mathrm{~h}$. The germination rate was calculated as shown in equation 1.

\subsection{Chemical composition analysis}

Chemical compositions of BR and GBR were determined according to [7]. Moisture content was performed by oven dried at $105^{\circ} \mathrm{C}$ for $5 \mathrm{~h}$. Ash content was done using a muffle furnace at $550^{\circ} \mathrm{C}$ for $24 \mathrm{~h}$. Protein content was determined using the Kjeldahl method. Fat content was evaluated by the Soxhlet extraction method. Fiber content was determined by sequential acid and alkali hydrolysis followed by oven dried. Total carbohydrates were calculated by subtracting the compositions from 100 [12].

GABA content of BR and GBR was analyzed by high performance liquid chromatography (HPLC, Infinity 1260 Agilent Technology, CA, USA), following [11] procedures.

\subsection{Microstructural analysis}

Field Emission Scanning Electron Microscope (FE-SEM, AURIGA, Carl Zeiss, Germany) was used to reveal the morphology of starch granules. The BR and GBR were placed on the metal stub and gold-sputtered; and 10,000x images of the micrograph were taken.

\subsection{Statistical analysis}

In this study, experiments were performed in duplicate. Results were expressed as means \pm standard deviations. One-way analysis of variance (ANOVA) was used to evaluate the effect 
of germination conditions. Tukey-HSD multiple comparison was used to compare means at $5 \%$ significance level $(\mathrm{p}<0.05)$ using Minitab ${ }^{\circledR} 17$ (Minitab Inc., USA).

\section{Results and discussion}

\subsection{Effect of germination conditions on germination rate of paddy}

In this study, the germination rate of germinated paddy was investigated under soaking at $30^{\circ} \mathrm{C}$ and $40^{\circ} \mathrm{C}$ for $2-24 \mathrm{~h}$, subsequently germination at $30^{\circ} \mathrm{C}$ for $48 \mathrm{~h}$ (Figure 1 ). The results showed that extended soaking time from 4-24 $\mathrm{h}$ insignificantly improved the germination rate $(95-99 \%)(\mathrm{p}>0.05)$. The findings were consistent with [5], who documented that soaking at $28^{\circ} \mathrm{C}$ for $24 \mathrm{~h}$ followed by germination at $34^{\circ} \mathrm{C}$ for $96 \mathrm{~h}$ of Ecuadorian brown rice resulted in highest germination rate (96-98\%). However, increased soaking temperature from 30 to $40^{\circ} \mathrm{C}(6-24 \mathrm{~h}$ soaking) slightly reduced the germination rate $(\mathrm{p}>0.05)$. It was probably because soaking at higher temperature increased in water content in the seeds resulting in reduction of germination rate [6]. [6] also reported that soaking of Khao Dok Mali 105 at $35^{\circ} \mathrm{C}$ for $12 \mathrm{~h}$ subsequently germination at $25^{\circ} \mathrm{C}$ for $24 \mathrm{~h}$ provided the highest GABA content of germinated brown rice $(17 \mathrm{mg} / 100 \mathrm{~g})$. Extended the soaking time from 12 to $24 \mathrm{~h}$ at $35^{\circ} \mathrm{C}$ significantly reduced GABA content $(7 \mathrm{mg} / 100 \mathrm{~g})$.

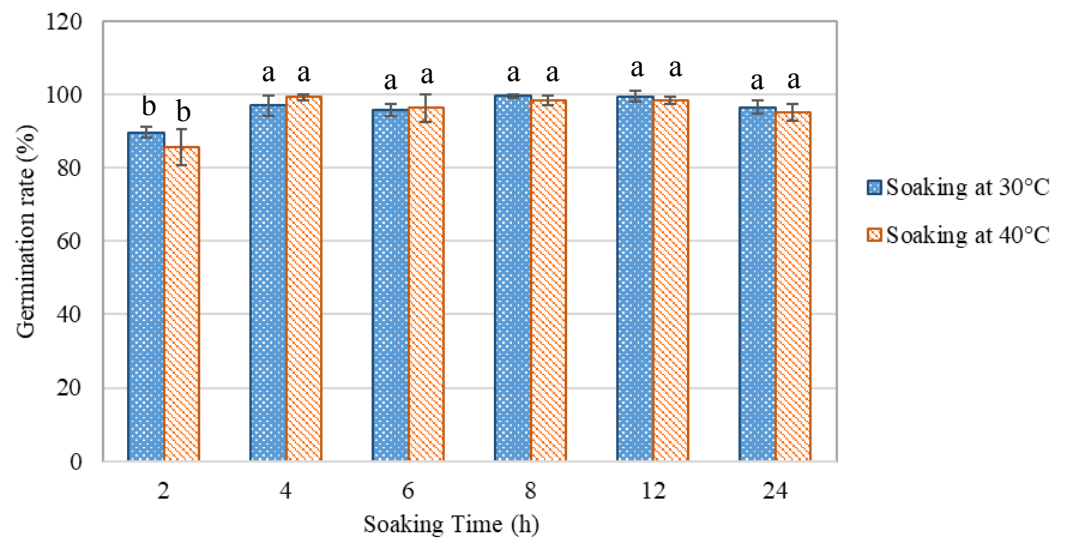

Fig. 1. Effect of soaking condition on germination rate of paddy, given the germination time and temperature of $48 \mathrm{~h}$ and $30^{\circ} \mathrm{C}$, respectively. Different letters in column represent significant differences between treatments $(\mathrm{p}<0.05)$.

Figure 2. showed the germination rate of germinated paddy on the effect of soaking and germination time at $30^{\circ} \mathrm{C}$. Extended the soaking time from 2 to $8 \mathrm{~h}$ and germination time from 14 to $36 \mathrm{~h}$ significantly increased the germination rate $(\mathrm{p}<0.05)$. The findings thus indicated that soaking times had effect on the germination rate with short germination times (24-36h). In addition, prolonged germination time to $48 \mathrm{~h}$ had impact on the germination rate. Further study is needed to investigate the germination rate of 12-24 h soaking and 14-36 h germination.

In this study, ultrasound was used to enhance germinating efficiency of paddy before or after soaking process. The results showed that ultrasound treatment had significant effect on germination rate when the soaked paddy was sonicated for $15 \mathrm{~min}$, and subsequently $24 \mathrm{~h}$ germination (UTA) (33\%) compared with non-ultrasound (NB) and ultrasound treatment before soaking $(\mathrm{UTB})(\mathrm{p}<0.05)$ as shown in Figure 3. These results could indicate that 
ultrasound treatment efficiently improved the germination rate when the sonication was applied after soaking process. The finding was consistent with [3], who documented that ultrasound treatment for $5 \mathrm{~min}$ after soaking process significantly improved the germinating speed when compared with sonication before soaking process. It was probably because the seeds were increased the porosity by ultrasound resulting in enhancing the oxygen and water absorption [3]. However, in this study, extended the germination time from 24 to $48 \mathrm{~h}$ of ultrasound treated paddy insignificantly increased the germinating efficiency, compared with non-ultrasound treated paddy $(\mathrm{p}>0.05)$.

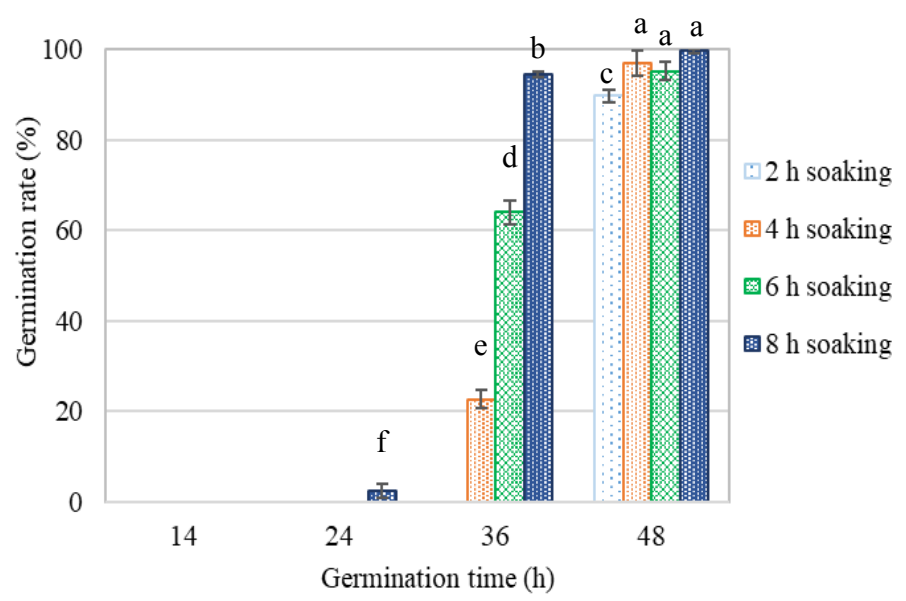

Fig. 2. Effect of soaking and germination time on germination rate of paddy given the soaking and germination temperatures of $30^{\circ} \mathrm{C}$. Different letters in column represent significant differences between treatments $(\mathrm{p}<0.05)$.

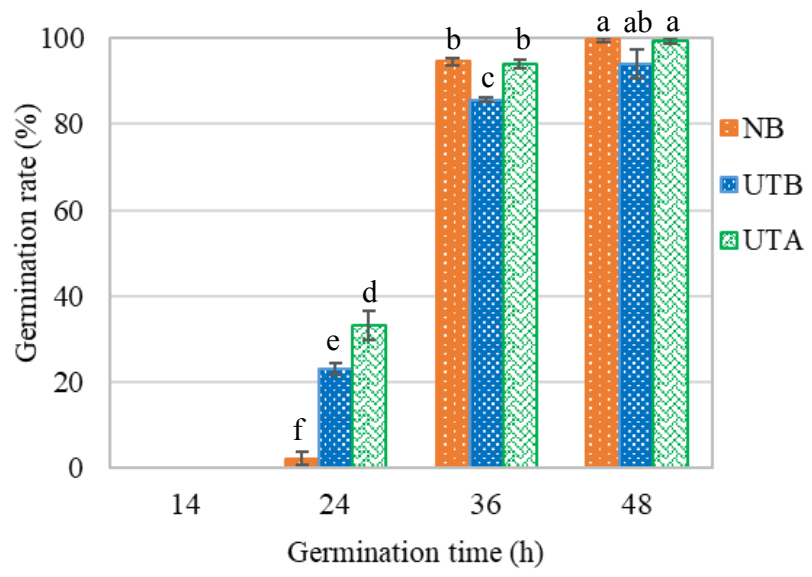

Fig. 3. Effect of ultrasound treatment on germination rate of paddy given the soaking time for $8 \mathrm{~h}$, and germination process temperatures of $30^{\circ} \mathrm{C}$. NB, UTB, and UTA denote non-ultrasound, ultrasound treatment before soaking, and ultrasound treatment after soaking. Different letters in column represent significant differences between treatments $(\mathrm{p}<0.05)$. 


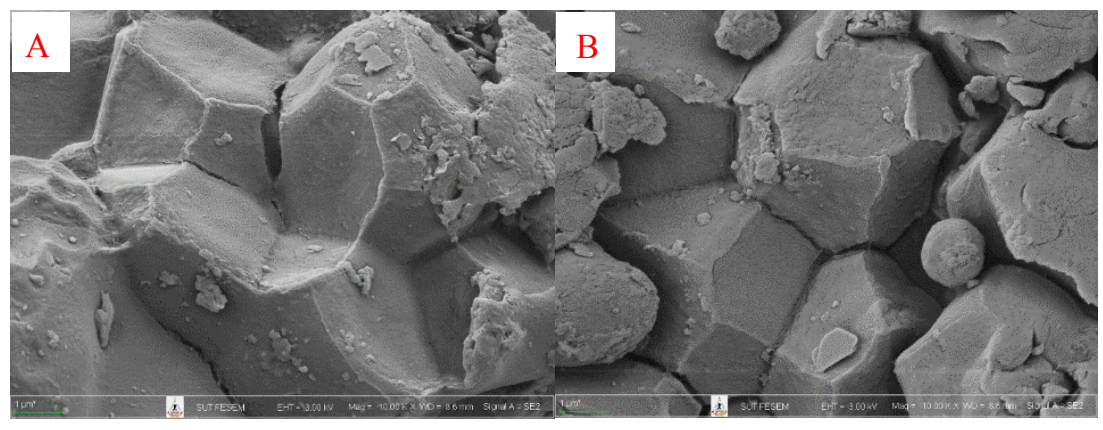

Fig. 4. The 10,000x FE-SEM images of (A) BR, (B) GB.

The FE-SEM images of BR and GB were presented in Figure 4. The starch granules of BR and GB had a smooth surface and a polyhedral shape. Therefore, these results indicated that the germination process had no effect on the surface and shape of starch granules of the GB, compared with BR. However, the starch granule of the GB was less compact than those of BR. This could be resulted in lower hardness or firmness value of GB. The finding is consistent with [8], who documented that germination process could reduce the size of starch granule of germinated brown rice resulting in a loose contact between starch granules.

\subsection{Chemical composition of BR and GB}

Table 1 shows the chemical composition of BR and GB obtained by $24 \mathrm{~h}$ soaking and $48 \mathrm{~h}$ germination, on dry weight basis. The crude protein, crude fat, crude fiber, ash, and total carbohydrate content of these samples were between $8.41-8.77 \%, 2.85-2.92 \%, 0.60-0.70 \%$, $0.48-0.85 \%$, and $85.58-87.30 \%$, respectively. These results indicated that the germination had no effect on changing the chemical composition of GB except the ash content, compared with BR. The finding is consistent with reported by [2]. In this study, the protein content in GB was slightly increased. It was probably due to the biochemical activity occurrence during germination process of the seed [2].

Table 1. Chemical composition of samples on dry weight basis.

\begin{tabular}{|c|c|c|c|c|c|}
\hline \multirow{2}{*}{ Treatment } & \multicolumn{5}{|c|}{ Chemical composition (\%) } \\
\cline { 2 - 6 } & Protein & Fat & Fiber & Ash & Carbohydrate \\
\cline { 2 - 6 } & $8.41 \pm 0.04$ & $2.92 \pm 0.18$ & $0.76 \pm 0.03$ & $0.85 \pm 0.05^{\mathrm{a}}$ & $85.58 \pm 0.74$ \\
\hline BR & $8.77 \pm 0.03$ & $2.85 \pm 0.09$ & $0.60 \pm 0.07$ & $0.48 \pm 0.09^{\mathrm{b}}$ & $87.30 \pm 0.20$ \\
\hline
\end{tabular}

${ }^{1}$ The values are the mean of three replications \pm standard deviation. Different letters in the column represent significant differences between treatments $(p<0.05)$. 
The GABA content of GB obtained by $24 \mathrm{~h}$ soaking and $48 \mathrm{~h}$ germination $(11.67 \mathrm{mg} / 100 \mathrm{~g})$ was significantly higher than that of BR $(1.08 \mathrm{mg} / 100 \mathrm{~g})(\mathrm{p}<0.05)$ as presented in Table 2 . The result was consistent with [6], who reported that GABA content of germinated brown rice ranged from 7-17 mg/100 $\mathrm{g}$ depending on the germination conditions. In addition, [9] documented that GABA in BR could not be detected, while the GABA content of dried germinated brown rice were $24.74-50.28 \mathrm{mg} / 100 \mathrm{~g}$. [14] reported that the soaking at $30^{\circ} \mathrm{C}$ for $24 \mathrm{~h}$ followed by germination at $35^{\circ} \mathrm{C}$ for $36 \mathrm{~h}$ of indica and japonica rice resulted in highest GABA content of germinated brown rice.

Table 2. GABA content of samples on dry weight basis.

\begin{tabular}{|c|c|}
\hline Treatment & GABA $(\mathbf{m g} / \mathbf{1 0 0} \mathbf{g})^{\mathbf{1}}$ \\
\hline BR & $1.08 \pm 0.15^{\mathrm{b}}$ \\
\hline GB & $11.67 \pm 0.32^{\mathrm{a}}$ \\
\hline
\end{tabular}

${ }^{1}$ The values are the mean of three replications \pm standard deviation. Different letters in the column represent significant differences between treatments $(\mathrm{p}<0.05)$.

\section{Conclusions}

This study investigated the influence of germination process (i.e., soaking and gemmation conditions, and ultrasound treatment) on the germination rate of GB. Increase soaking temperature from $30^{\circ} \mathrm{C}$ to $40^{\circ} \mathrm{C}$ did not improve the germination rate. However, extended soaking and germination time resulted in increasing the gemmation rate. While, ultrasound treatment for $15 \mathrm{~min}$ on the soaked paddy enhanced the germination of $24 \mathrm{~h}$ germinating time. GABA content of GB obtained by $48 \mathrm{~h}$ germination was significantly higher than that of BR. Further work is needed to investigate the bioactive compounds content (i.e., GABA, phenolics, gamma oryzanol, and antioxidant activity) of GB, and assess an optimal germination condition.

The authors would like to thank Suranaree University of Technology for supporting the External Grants and Scholarships for Graduate Students (OROG); and contributing facilities to achieve this study.

\section{References}

1. A. Eamarjharn, C. Theerakulkait, S. Thanachasai, Agr. Nat. Resour. 50, 80 (2016)

2. A. Moongngarm, N. Saetung, Food Chem. 122, 782 (2010)

3. J. Ding, A.V. Ulanov, M. Dong, T. Yang, B.V. Nemzer, S. Xiong, S. Zhao, H. Feng, Ultrason. Sonochem. 40, 791 (2018)

4. K. Umnajkitikorn, B. Faiyue, K. Saengnil, J. Rice Res. 1 (2013)

5. P. J. Cáceres, C.M. Villaluenga, L. Amigo, J. Frias, Food Chem. 152, 407 (2014)

6. P. Sirisoontaralak, N.N. Nakornpanom, K. Koakietdumrongkul, C. Panumaswiwath, LWT-Food Sci. Technol. 61, 138 (2015)

7. S.O. Serna-Saldivar, Cereal grains laboratory reference and procedures manual (CRC Press (Taylor \& Francis Group), Boca Raton, 2012) 
8. T. Chungcharoen, S. Prachayawarakorn, P. Tungtrakul, S. Soponronnarit, Food Bioprod. Process. 94, 707 (2015)

9. T. Tumpanuvatr, W. Jittanit, V. Surojanametakul, J. Stored Prod. Res. 77, 177 (2018)

10. W. Srichamnong, P. Thiyajai, S. Charoenkiatkul, Food Chem. 191, 113 (2016)

11. W. Varanyanond, P. Tungtrakul, V. Surojanametakul, L. Watanasiritham, W. Luxiang, Kasetsart J. (Nat. Sci.) 39, 411 (2005)

12. W. Watchararparpaiboon, N. Laohakunjit, O. Kerdchoechuen, Food Sci. Tech. Int. 16, 147 (2010)

13. Q. Xia, H. Tao, Y. Li, D. Pan, J. Cao, L. Liu, X. Zhou, F.J. Barba, Food Control 108 (2020)

14. Q. Zhang, J. Xiang, L. Zhang, X. Zhu, J. Evers, W.V.D. Werf, L. Duan, J. Funct. Foods 10, 283 (2014) 